\title{
Czasownik stracić i jego właściwości Analiza semantyczno-składniowa
}

Słowa klucze: jednostka języka; właściwości semantyczno-składniowe; ograniczenia selekcyjne; reprezentacja semantyczna

Keywords: linguistic unit; semantic and syntactic characteristics; selectional restrictions; semantic representation

W sztuce tracenia nie jest trudno dojść do wprawy; tak wiele rzeczy budzi w nas zaraz przeczucie straty, że kiedy się je traci-nie ma sprawy.

(E. Bishop)

W artykule tym podejmę próbę opisu właściwości semantyczno-składniowych wyrażenia stanowiącego nazwę zdarzenia, które jest powszechne i dotyka każdego człowieka, choć w większości wypadków każdy z nas chciałby go uniknąć. Mam tu na myśli czasownik stracić, który będzie przedmiotem mojej analizy. Wybór formy dokonanej podyktowany jest dwoma względami: po pierwsze, przyjmuję (m.in. za A. Bogusławskim (2001: 71)), że forma dokonana czasownika jest prostsza pod względem semantycznym od formy niedokonanej, po drugie, charakterystyka formy niedokonanej tracić byłaby kłopotliwa ze względu na to, że tworzy on pary aspektowe z innymi czasownikami przedrostkowymi - utracić i zatracić, por.: 
(1) Zazwyczaj tracit wszelka rachubę, nie wiedzac, jak wiele przeszedt.

(1a) Zatracit wszelka rachubę, nie wiedziat, jak wiele przeszedt.

(2) Wjej towarzystwie Teofil tracit wszelka swobode.

(2a) W jej towarzystwie Teofil utracit wszelka swobodę.

W artykule nie będę podejmować problemu wzajemnych relacji czasowników stracić, utracić i zatracić, choć zagadnienie to jest niewątpliwie interesujące. Szczególnie ważne jest rozstrzygnięcie, czy różnica między wymienionymi wyrażeniami, wywodzącymi się z jednego źródłosłowu ${ }^{1}$, wynika z właściwości semantycznych, czy jest czysto pragmatyczna ${ }^{2}$. Nie stanowią również przedmiotu mojego zainteresowania całostki, których składnikiem jest czasownik stracić, takie jak stracić [kogoś] z oczu, stracić twarz, stracić głowę czy stracić [coś: głowę, rozum] dla [kogoś], por.:

(3) Reporter stracit głowę $i$ wygadywał głupstwa, mylac się bez przerwy.

(4) Zupetnie stracił głowę dla dziewczyny, która pierwszy raz w życiu zobaczyt.

(5) Ktoś, kto stracit twarz, bardziej zasługuje na wzgardę niż na wspótczucie.

(6) Piotr stracit go z oczu, ale ustyszał dźwięk otwieranych drzwi wejściowych.

Wymienione wyrażenia wykazują jedynie podobieństwo formalne oparte są na wspólnym elemencie - powinny być analizowane i opisywane jako odrębne obiekty.

${ }^{1}$ Czasowniki stracić, utracić, wytracić < pol. tracić < psł. *tratiti 'zużywać coś, niszczyć, marnować, pozbywać się czegoś' (pierwotnie 'trzeć, rozcierać') od pie. *trōt- / *têr-t- opartego na pierwiastku *ter- 'trzeć' (Boryś 2010: 639). Do grupy tej należy także czasownik zatracić się, który tworzy parę aspektową z formą zatracać się i jest najbardziej odległy semantycznie.

2 Można bowiem przypuszczać, że są to jedynie różnice stylistyczne, na co wskazywać by mogła wymienność omawianych wyrażeń w różnych kontekstach (a brak ekwiwalencji również może być podyktowany względami pragmatycznymi). Jeśli rzeczywiście tak jest, to czasownik stracić należałoby uznać za neutralny względem utracić i zatracić. Przy czym leksem zatracić odczuwam jako przestarzały. 


\section{Ksztalt dwumiejscowej jednostki reprezentowanej przez czasownik stracić}

Interesować mnie będzie dwumiejscowy czasownik stracić - $\mathrm{z}$ argumentami lewo- i prawostronnym. I w tym miejscu chciałabym zastanowić się nad możliwościami realizacji tych właśnie pozycji przyczasownikowych, co pozwoli mi ustalić kształt analizowanej jednostki. Zacznę od argumentu lewostronnego (mianownikowego), a dokładnie od pytania, czy pozycję tę, obok wyrażeń redukowalnych do wyrażenia ktoś, mogą realizować również wyrażenia, które dadzą się sprowadzić do zaimka coś. Spójrzmy na przykłady (7) - (17):

(7) Bez Martyny wycieczki stracity sens.

(8) Kanat stracił znaczenie dla żeglugi towarowej.

(9) A teraz życie straciło dla niej wartość.

(10) Masz w domu zbędne suche liście i róże, które stracity urok?

(11) Samolot stracit skrzydto i spadt na ziemię.

(12) Nie była ranna, choć obłożony workami samochód stracit kolejnq szybę.

(13) Drezno ma nowy most, ale straciło miejsce na liście UNESCO.

(14) Jakiś czas temu azalia straciła najpierw kwiaty, a chwile później liście. ${ }^{3}$

(15) Czerń straciła nasycenie, więc ja troche poprawiłam.

(16) Na jak dtugo GKS Katowice stracit najlepszego zawodnika?

(17) Czyżby romantyzm stracił zwolenników?

W powyższych przykładach w pozycji mianownikowej znalazły się zarówno argumenty przedmiotowe, jak i nieprzedmiotowe: zdarzeniowe i niezdarzeniowe (nazwy cech abstrakcyjnych) - wszystkie redukowalne do wyrażenia coś. Zauważyć jednak należy, że przykłady (7) - (10) tylko z pozoru są zbudowane na czasowniku dwumiejscowym. Według mnie, stanowią realizację jednostki trójargumentowej o kształcie:

$\left[\operatorname{coś}_{\mathrm{i}: \mathrm{M} .}\right]$ straciło $\left[\operatorname{coś}_{\mathrm{j}: \mathrm{B} .}\right]$ dla $\left[\operatorname{kogos} \text { k: } \mathrm{D}_{\mathrm{D}}\right]^{4}$.

3 Przyjmuję, że nazwy roślin redukują się do jednostki coś.

4 W przykładzie (8) Kanat stracił znaczenie dla żeglugi towarowej. w pozycji dopełniaczowej stoi wyrażenie, które sprowadza się do zaimka coś, ale w strukturze głębokiej odsyła do kogoś (osób pracujących w żegludze towarowej). 
Bowiem w wypowiedziach, w których nadawca stwierdza, że wycieczki straciły sens czy życie straciło wartość, nie podaje się faktów. Nadawca mówi w nich o sobie i o swoich względem czegoś odczuciach, z którymi odbiorca wcale nie musi się zgadzać czy utożsamiać. Widać to dobrze w poniższym tekście, por.:

(18) Duduś wcale się nie ucieszyt. Zrobit jamnikowata minę i powiedziat: „Phi, teraz cała podróż straciła urok”. Dla mnie podróż wcale nie straciła uroku.

Strukturę powierzchniową pozostałych wypowiedzi (11) - (17) przedstawić można jako [coś $]$ straciło [coś $]$, a nawet [cośs $]$ straciło [kogoś $]$ ]. Przykłady te jednak nie stanowią realizacji analizowanej przeze mnie jednostki ${ }^{5}$. Jest to związane z jej właściwościami semantycznymi, a dokładnie z informacją, jaką niesie ze sobą wyrażenie stracić - komunikuje, że ktoś nie chciał tego, co się stało. Do kwestii tej wrócę w dalszej części artykułu, bowiem problem ograniczeń pozycji lewostronnej wymaga dalszego komentarza.

Wśród wypowiedzi korpusowych (NKJP) odnaleźć można przykłady, w których w pozycji mianownikowej stoją zarówno nazwy osobowe, jak i nazwy zwierząt, por.:

(19) Misiek stracit dom i ukochanego właściciela.

(20) Młode zostaty podrzucone po wypadku, w którym ptaki stracity gniazdo.

(21) Przygarnięte do ośrodka ptaki stracity rodziców przed opanowaniem latania.

Nie są to jednak zwykłe realizacje analizowanej jednostki. Podobnie jak w wypadku przykładów z wyrażeniami redukującymi się do wyrażenia coś, istnieją ograniczenia semantyczne, które sprawiają, że nazwy zwierząt muszą zostać wyłączone z wyrażeń, które konotuje czasownik stracić. Moim zdaniem, kluczowa jest tu możliwość uświadomienia sobie poniesionej

${ }^{5}$ Nie odzwierciedlają też odrębnych jednostek języka. Można powiedzieć, że stanowią jednostkę operacyjną, czyli taką, która jest rezultatem operacji na istniejącej w systemie jednostce (operacji metaforyzacji). 
straty, która implikuje możliwość powiedzenia o tym ${ }^{6}$. Również i do tej kwestii powrócę przy omawianiu właściwości semantycznych.

Jeśli zaś chodzi o pozycję prawostronną, to realizować ją mogą zarówno wyrażenia redukowalne do ktoś, jak i do coś. Tu może się nasunąć pytanie, czy stracić [kogoś.] jest tym samym wyrażeniem, co stracić [cośs]. Myślę, że nie należy doszukiwać się tu dwóch jednostek, co potwierdza fakt, że mogą one wystąpić w koniunkcji, por.:

(22) Tylko z powodu własnej głupoty stracił udziały w firmie $i$ wspólnika.

(23) Stracit kobiete, która kochat, i dom, który budowat.

(24) Straciła prawdziwego przyjaciela i nadzieję na lepsze życie.

W związku z powyższym postulowany przeze mnie kształt jednostki to:

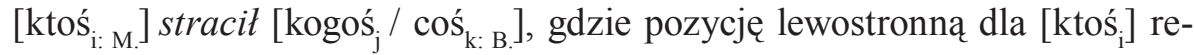
alizować mogą tylko nazwy osobowe. Problem, który pozostaje, to ograniczenia selekcyjne narzucane przez czasownik na pozycję drugą, czyli odpowiedź na pytanie, które wyrażenia redukowalne do jednostek elementarnych ktoś i coś mogą stać w tej pozycji (a także, które tej pozycji nie mogą realizować i dlaczego).

\section{Czasownik stracić w słownikach współczesnej polszczyzny}

Słowniki współczesnej polszczyzny uznają czasownik stracić za leksem wieloznaczny, przypisując mu nawet dziesięć znaczeń (por. ISJP). Spójrzmy zatem na definicje słownikowe:

Uniwersalny słownik języka polskiego (Dubisz 2003)7:

1. «przestać coś mieć, zostać bez kogoś lub bez czegoś, zostać wbrew swojej woli pozbawionym kogoś lub czegoś»: Stracić rodzinę. Stracić posadę.

${ }^{6}$ Por. co na ten temat A. Bogusławski: „«świadomość, że $F a »$ obejmuje wiedzę, że $F a$, ale się do niej nie ogranicza: należy do niej także «mówienie, że $F a$ » (w sensie mentalnym)" (Bogusławski 1988: 58).

7 Przy definicjach słownikowych nie zachowałam kolejności chronologicznej i jako pierwszy wymieniłam USJP ze względu na to, że jego podstawą był Słownik języka polskiego pod red. Mieczysława Szymczaka, wydawany na przełomie lat 70. i 80. $\mathrm{XX}$ wieku. 
2. «ponieść stratę materialną, doznać uszczerbku na czymś»: Stracić na handlu. Stracić na sprzedaży domu.

3. «nie wykorzystać czegoś, zmarnować, przepuścić coś; roztrwonić»: Stracić okazję. Stracić majatek, grajac w karty.

4. a) «stać się gorszym, mniej wartościowym wskutek czegoś, z powodu jakichś niesprzyjających okoliczności; ucierpieć»: Okolica wiele straciła wskutek wycięcia lasu. b) «wykonać na kimś wyrok śmierci»: Stracić skazańców, więźniów.

Inny słownik języka polskiego (Bańko 2000):

1. Jeśli jakaś osoba, rzecz, sytuacja itp. straciła coś, to przestała to mieć lub charakteryzować się tym. Wczoraj 100 tys. osób straciło prawo do zasitku...

2. Jeśli straciliśmy coś, np. czas siły lub pieniądze, to zużyliśmy to bez potrzeby lub niewłaściwie. Stracilem na te poszukiwania dużo czasu...

3. Jeśli ktoś stracił na jakimś przedsięwzięciu lub zachowaniu, to jego sytuacja pogorszyła się, np. ma mniej pieniędzy lub gorszą opinię. $\mathrm{Na}$ imporcie na pewno nie stracisz...

4. Jeśli ktoś stracił krewnego lub przyjaciela, to jego krewny lub przyjaciel umarł, zginął lub odszedł od niego na zawsze. $W$ powstaniu straciła męża i syna...

5. Jeśli straciliśmy szansę, to nie wykorzystaliśmy jej. Przez głupote stracit takq okazję...

6. Mówimy, że ktoś stracił rozum lub zmysły, jeśli popadł w chorobę psychiczną lub zaczął zachowywać się jak psychicznie chory. Poldek, dziecko, rozum straciłeś?

7. Jeśli ktoś stracił pewną liczbę kilogramów, to stał się o tyle lżejszy.

8. Jeśli jakaś osoba lub rzecz straciła ciepło, które powinna była zatrzymać, to oddała je, np. z powodu złego ubioru lub niewłaściwej izolacji.

9. Jeśli zawodnik lub zespół sportowy stracił bramkę lub punkt, to jego przeciwnik zdobył bramkę lub punkt.

10. Jeśli ktoś stracił życie, to umarł. 
Wielki stownik języka polskiego (Żmigrodzki 2007-)

1. [wzrok] «przestać mieć daną cechę, zdolność do czegoś, zmysł»: Po śmierci męża straciła wzrok, po wylewie przestała chodzić i mówić.

2. [dobytek] «przestać posiadać coś, co uprzednio się dostało lub zdobyło»: Miliony ludzi straciło pracę i środki do życia.

3. [żonę] «znaleźć się w sytuacji, w której ktoś z bliskiego otoczenia przestaje w nim być z powodu śmierci albo rozstania»: Przeraża mnie myśl, że mogę kiedyś stracić ukochanq osobę.

4. [kilogramy] «przestać mieć coś, co do tej pory stanowiło element budowy jakiegoś organizmu»: Ten jednak w toku ewolucji stracit pióra.

5. [czas] «zużyć coś niewłaściwie, marnotrawiąc to»: Zanim dojechat do pit stopu, stracit mnóstwo cennych sekund.

6. [okazję] «znaleźć się w sytuacji takiej, że to, o czym komunikuje następujący rzeczownik, minęło i nie można już z tego skorzystać»: Przez chorobę straciła szansę na wystapienie $w$ roli Julii $w$ którymś z pokazów przedpremierowych.

7. [bramkę] «znaleźć się w sytuacji, w której przeciwnik zdobywa w grze bramkę, punkt»: Szybko straciliśmy gola i musieliśmy ciężko pracować, żeby w końcu wywalczyć trzy punkty.

Jak widać z powyższych definicji, kluczową rolę w wyróżnianiu i opisywaniu znaczeń czasownika stracić odegrała w pierwszym rzędzie łączliwość (a dokładnie wyrażenia stojące w drugiej pozycji), a następnie sposób, w jaki coś się straciło (na co wskazują użyte wyrażenia: zostać pozbawionym, zmarnować, przepuścić, roztrwonić, nie wykorzystać).

Wstępny ogląd zarejestrowanych przez słowniki przykładów wskazuje na to, że część definicji odnosi się do odrębnych jednostek języka. Za takie intuicyjnie uznałabym chociażby [ktoś $\left.{ }_{\mathrm{i}: \mathrm{M}}\right]_{\text {stracit } n a}$ [czymśs $\mathbf{c}_{\mathrm{j}: \mathrm{Msc}}$ ], [ktoś ${ }_{\mathrm{i}: \mathrm{M}}$ ] stracił rozum, [cośs i: $_{\mathrm{M}}\left(\right.$ implikujące ktoś) ${ }_{\mathrm{i}}$ ] stracit bramkę czy komen-

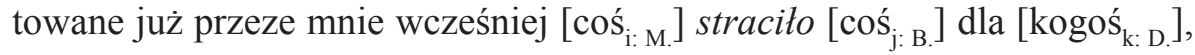
gdzie mamy do czynienia z oceną nadawcy, a której realizację stanowi wypowiedź ze znaczenia 4.a. w USJP, choć na pierwszy rzut oka wcale tak nie wygląda (informacja o przyczynie straty nie jest istotna $\mathrm{z}$ punktu widzenia cech definicyjnych). 


\section{Wlaściwości semantyczne jednostki [ktoś $\left.{ }_{\mathrm{i}: \mathrm{M} .}\right]$ stracil $\left[\mathrm{kogos}_{\mathrm{j}} / \cos _{\mathrm{k}: \mathrm{B}}\right.$ ]}

Omawiane słowniki wskazują na element 'przestać mieć' jako składnik znaczenia stracić, co jest zgodne z intuicją chyba każdego użytkownika polszczyzny. O wyrażeniach zawierających ten element pisała Zofia Zaron (1975). W swoim artykule omawiała takie czasowniki jak dać, oddać, ofiarować, podarować czy przekazać. Od czasownika stracić różni je obecność w strukturze adresata oraz chcenie, którym odznacza się agens, żeby przestać mieć. Wydaje się, że czasowniki, w których znaczenia można wskazać element 'przestać mieć', da się podzielić na dwie grupy ze względu na dodatkowy składnik 'chcieć' lub 'nie chcieć'. Do tej, w której powiedziane byłoby, że ktoś chciał przestać mieć, należałyby np. oddać, wyrzucić, pozbyć się, prze$k a z a c ́$, do drugiej zaś stracić czy zgubić, które informowałyby o tym, że nie chciał. Widać to w przykładach:

(25) Jan stracit majątek. - *Rozdat go biednym.

(26) Jan stracit w tamtym roku wspólnika. - *Zerwat z nim umowę.

(27) Jan stracil cenne pióro. - *Oddat je bratu.

Druga wypowiedź jest sprzeczna z pierwszą właśnie ze względu na zestawienie 'nie chcieć' i 'chcieć'. W wypadku czasownika stracić składnik 'nie chcieć' umieściłabym w presupozycji. Podobnie jak element 'mieć', którego obecność jest tu raczej oczywista. Nie można bowiem stracić czegoś, czego się nigdy nie miało. To, że jest on w presupozycji, pokazują poniższe wypowiedzi, por.:

(28) Po tym zdarzeniu Jan stracit ochotę na spotkanie z Mariq.

(29) Mimo wszystko Jan nie stracił ochoty na spotkanie z Mariq.

(30) Na nieszczęście stracił wtedy dużo pieniędzy.

(31) Na szczęście nie stracił wtedy pieniędzy.

(32) Po aresztowaniu stracit przyjaciót.

(33) Mimo aresztowania nie stracit przyjaciót.

Widać zatem, że element 'mieć' nie podlega negacji. Zarówno wtedy, kiedy mówimy, że ktoś stracił, jak i wtedy, kiedy orzekamy, że ktoś nie stracił, mówimy, że to miał, por.: 
(31a) *Na szczęście nie stracit wtedy pieniędzy, ale to nieprawda, że miat wtedy pieniqdze.

(33a) *Mimo aresztowania nie stracit przyjaciól, ale to nieprawda, że miat wtedy przyjaciót.

Oczywiście, nie wyklucza to istnienia wypowiedzi typu Nie stracit pieniędzy, bo ich nigdy nie miat., ale uznać je należy za grę językową, wykorzystującą właśnie to, że 'mieć' przy wyrażeniu stracić jest konieczne. I jest to wystarczająca informacja. Niepotrzebne (i mylące zarazem) jest wprowadzanie do definicji informacji o sposobie, w jaki ktoś zaczął mieć to, co stracił, tak jak to jest w WSJP, gdzie czytamy o stracie tego, „, co uprzednio się dostało lub zdobyło". A już na pewno nie może być to informacja, która daje podstawę do wyróżnienia kolejnego znaczenia.

Autorzy słowników dużo więcej miejsca poświęcają jednak sposobowi, w jaki ktoś coś (lub kogoś) stracił. Do definicji wprowadzają takie informacje jak „zostać pozbawionym czegoś lub kogoś” czy „nie wykorzystać czegoś”, zestawiają też czasownik stracić z wyrażeniami typu zmarnować, przepuścić czy roztrwonić. I w tym wypadku jednak należy zrezygnować $\mathrm{z}$ wprowadzania informacji o sposobie do definicji. Nie sposób jest tu bowiem ważny, a rezultat.

Z problemem sposobu wiąże się kwestia orzekania o tym, czy ktoś przyczynił się do tego, że przestał mieć, czy nie. Odpowiedź pozytywną narzucają wymienione w słownikach czasowniki zmarnować, przepuścić i roztrwonić (których obecność przy definicji jest konsekwencją łączliwości stracić z wyrażeniami szansa, okazja, pieniqdze czy majatek). Spójrzmy na przykłady:

(34) Marek zmarnowat ostatniq szansę.

(35) Marek stracit ostatniq szansę.

(36) Marek zmarnowat dzień.

(37) Marek stracił dzień.

W wypadku czasownika zmarnować nadawca przesądza o odpowiedzialności osoby, o której mówi, natomiast przy czasowniku stracić jednoznacznej informacji o tym, czy ktoś się przyczynił do zaistniałego stanu, nie ma. Jak już pisałam w części dotyczącej składnika 'nie chcieć', osoba, która 
straciła, nie mogła dążyć do tego świadomie. Natomiast nie chcąc, mogła się do straty przyczynić. Nie uważam jednak informacji o tym, że ktoś zrobił coś lub nie zrobił czegoś, co mogło spowodować to, że stracił, za element struktury semantycznej wyrażenia stracić. Brak takiej informacji odróżnia je już od wymienionych wcześniej czasowników.

Chciałabym omówić jeszcze kwestię reakcji na stratę. Informacja o tym, że stało się coś, czego ktoś nie chciał, sprawia, że łatwo nam się domyślić, że nie jest on z tego zadowolony. Oczekujemy wręcz, że nie pozostanie wobec zaistniałego faktu obojętny. Takie oczekiwania zgodne są z tym, co komunikuje czasownik stracić. Stąd uważam, że wypowiedź taka jak:

(38) Marek stracit wroga.

może wydawać się dziwna z tego względu, że zakładamy, że nikt nie chce mieć wrogów. Widać to, kiedy porównamy stracić z czasownikiem zgubić, który nie informuje o tym, że coś, co zostało zgubione, było z jakichś względów ważne. Nie każde bowiem zgubienie czegoś nazwiemy stratą, por.:

(39) Marek zgubil guzik od marynarki, nie przejat się tym, bo ma zapasowy.

(40) ? Marek stracit guzik od marynarki, nie przejąt się tym, bo ma zapasowy.

(41) Zgubiłem po drodze pióro. Drobiazg! Nie warto się tym przejmować.

(42) ? Stracilem swoje pióro. Drobiazg! Nie warto się tym przejmować.

W związku z tym uważam, że w definicji powinna się znaleźć informacja o tym, że osoba, która coś lub kogoś straciła, nie uważa zaistniałej sytuacji za mało ważna.

Podsumowując moje wstępne rozważania dotyczące składników definicyjnych, chciałabym zaproponować (roboczą) definicję omawianej jednostki.

[ktośs $\left.{ }_{\mathrm{i}: \mathrm{M}}\right]$ stracit $\left[\operatorname{kogos}_{\mathrm{j}} / \cos _{\mathrm{k}: \mathrm{B}}\right]=$

P.: 'ktoś ${ }_{\mathrm{i}}$ miał kogoś $/$ cośs $_{\mathrm{k}} \mathrm{i}$ nie chciał nie mieć kogoś./czegoś ${ }_{\mathrm{k}}$,

A.: ktoś ${ }_{i}$ od pewnego momentu nie ma kogoś. /czegoś $_{\mathrm{k}} \mathrm{i}$ jest gotów powiedzieć, że nie jest dobrze, że tak jest'. 
Kolejny problem to wiedza tego, kto stracił kogoś lub coś, a dokładnie kwestia tego, czy człowiek może nie wiedzieć o tym, że stracił (wtedy nie może nic na ten temat powiedzieć). I nie chodzi mi tu tylko o wypowiedzi typu Nie wiesz, co stracileś., ale o takie, jak w poniższych przykładach:

(43) Stracił wtedy taka okazje i do tej pory o tym nie wie.

(44) Nie ma pojęcia, że przez tę wypowiedź stracił część swoich zwolenników.

(45) Nie wie, że stracit swojego najwierniejszego fana.

Myślę, że użycie w tych wypowiedziach czasownika stracić jest jak najbardziej uzasadnione, o interpretacji zdarzenia decyduje bowiem nadawca (który bierze odpowiedzialność za użycie takiego, a nie innego, wyrażenia).

\section{Problemy z prawostronną pozycją [ktośs $\hat{\mathrm{i}}_{\mathrm{M} \text {. }}$ ] stracil $\left[\mathrm{kogos}_{\mathrm{j}} / \cos _{\mathrm{k}: \mathrm{B}}\right.$ ]}

Taki kształt definicji wiąże się z konsekwencjami w postaci pozostawienia wyrażeń, których ona nie obejmuje. Chodzi tu dokładnie o wyrażenia, które mogłyby realizować pozycję prawostronną. To m.in. nazwy zmysłów: wzrok, słuch, węch, ale też rachuba, trop, rozsqdek, życie, a nawet ciepło. Nienaturalny bowiem wydaje się zapis mieć wzrok, rachubę czy ciepło. Zauważyć jednak należy, że wyrażenia te nie funkcjonują na tych samych zasadach, co inne, mogące realizować omawianą pozycję, jak czas, majatek, szansa. Różnice te uwidaczniają się w połączeniach np. z imiesłowem biernym stracony (dotyczy to jednak tylko wyrażeń redukowalnych do zaimka coś), por.:

(46) Często rozmyśla o straconym czasie (majatku, straconej szansie)., ale:

(47) ? Często rozmyśla o straconym wzroku (cieple, rachubie).

Różnice spowodowane są tym, że wyrażenia te tworzą odrębne jednostki języka, które konstytuuje czasownik stracić. Połączenia zawierające nazwy zmysłów (być może i wyraz życie) należą do terminologii specjalistycznej medycznej (por. utrata wzroku - ?strata wzroku, utrata życia - ?strata życia), tak jak połączenie z wyrażeniem ciepło należy do terminologii fizycznej. Natomiast stracić rachubę czy stracić rozsqdek to zleksykalizowane zwroty. 
Jednostek, które zawierają kształt stracić, może być jednak dużo więcej. W III sondzie słownikowej A. Bogusławski i M. Danielewiczowa (2005: 259) uznali za odrębną jednostkę również [ktoś $]$ stracit panowanie nad kierownica, definiując ją jako ' $i$ przestał mieć wpływ na ruch pojazdem, którym $i$ kierował'. W związku z tym za odrębne wyrażenie trzeba zapewne uznać [ktoś.] stracił panowanie nad sobq. Kandydatem na kolejną odrębną jednostkę języka byłby również kształt [ktoś ${ }_{\mathrm{i}}$ stracit nadzieję, $\dot{z} e_{-}$, analogicznie do jednostek typu [ktoś] ma nadzieję, że_i [ktośs] żywi nadzieje, że_ (por. Bednarek 1991: 220, Danielewiczowa 2002: 258). Każdą z powyższych jednostek, a także te, które wymieniłam wcześniej, należy omówić oddzielnie.

Tak duża liczba jednostek języka, których członem konstytuującym jest czasownik stracić, nastręcza wielu problemów przy opisie właściwości semantycznych oraz wynikających z nich ograniczeń selekcyjnych. Szczególnie trudne (choć nie tylko w wypadku tej jednostki) jest oddzielenie wyrażeń, które realizują prawostronną pozycję, od tych, które tworzą z czasownikiem stracić odrębne wyrażenie.

\section{Bibliografia}

Bednarek A., 1991, O nadziei. Próba definicji semantycznej, w: Bartmiński J., Puzynina J. (red.), Język a kultura, t. 2: Zagadnienia leksykalne i aksjologiczne, Wrocław: Wiedza o Kulturze, s. 325-353.

BogusŁawski A., 1988, Jezzyk w stowniku. Desiderata semantyczne do wielkiego stownika polszczyzny, Wrocław: Zakład Narodowy im. Ossolińskich.

BogusŁawski A., 2001, Pary czy wieloczłony aspektowe?, Prace Filologiczne XLVI, s. $69-70$.

BogusŁawski A., Danielewiczowa M., 2005, Verba polona abscondita: sonda stownikowa III, Warszawa: Elma Books.

BoRYś W., 2010, Stownik etymologiczny języka polskiego, Kraków: Wydawnictwo Literackie.

Danielewiczowa M., 2002, Wiedza i niewiedza. Studium polskich czasowników epistemicznych, Warszawa: Katedra Lingwistyki Formalnej UW.

ISJP - Bańko M. (red.), 2000, Inny stownik języka polskiego, t. 2, P-Ż, Warszawa: Wydawnictwo Naukowe PWN.

NKJP - Narodowy Korpus Języka Polskiego - PELCRA [on-line:] nkjp.pl.

USJP - DuBISz S. (red.), 2003, Uniwersalny słownik języka polskiego, Warszawa: Wydawnictwo Naukowe PWN. 
ZARON Z., 1975, Niektóre słowa z elementem „zaczać/przestać mieć” [w:] Janus E. (red.), Słownik i semantyka. Definicje semantyczne, Wrocław: Zakład Narodowy im. Ossolińskich, s. 105-110.

ŻMigrodZKi P. (red.), 2007-, Wielki słownik języka polskiego [on-line:] www.wsjp.pl.

\section{Semantic and Syntactic Analysis of Verb stracić}

\section{( s u m m a r y)}

The purpose of the article is to describe semantic and syntactic characteristics of one of many linguistic units containing the form stracić (to lose). Dictionaries of contemporary Polish language consider stracić as a one, polysemous unit. Nevertheless, there are at least several units which are represented by the form of stracić, among others, [ktoś] stracit [kogoś] z oczu, [ktoś] stracit głowe, [ktoś] stracit panowanie nad sobq, as well as [coś] straciło [coś] dla [kogoś], which is very similar to the analyzed unit. The unit, which is the subject matter of the article is [ktoś] stracił [kogoś/coś]. The author, by analysis syntactic and semantic characteristics of the unit, attempts to define its selectional restrictions and tries to answer the question on what this unit might mean. As a result, a representation of its semantic content is presented. 
